\title{
Membangun Bangsa yang Sehat Produktif
}

\section{Does Sampoerno*}

\begin{abstract}
Abstrak
Peran kesehatan yang dipahami pihak ekeskutif dan legislatif di Indonesia masih terbatas pada pengobatan dan penyembuhan penyakit, bukan membangun sumber daya manusia yang berkualitas. Sejak masa penjajahan, kebijakan kesehatan tersebut didominasi oleh kebijakan kuratif dengan fasilitas kesehatan utama Rumah Sakit, Puskesmas dan Balai Pengobat. Upaya kesehatan tersebut melemahkan argumentasi peran penting kesehatan dalam pembangunan bangsa. Konsep tersebut berpengaruh terhadap tujuan upaya kesehatan mencapai keadaan sehat produktif untuk semua yang dapat mengantarkan penduduk mencapai tingkat sehat produktif. Definisi sehat yang baru tersebut berpengaruh terhadap perubahan paradigma penanganan kesehatan dari "Health Program for Survival" ke "Health Program for Human Development". Tujuan akhir program kesehatan berubah menjadi sehat produktif yang bernilai ekonomis bagi sebagian besar penduduk. Hak azasi kesehatan menurut WHO mencakup hak informasi, privasi, menikmati kemajuan teknologi kesehatan, pendidikan kesehatan, ketersediaan makanan dan gizi, mencapai standard hidup optimal, dan jaminan sosial. Sudah saatnya upaya kesehatan tidak lagi bertumpu pada pengobatan penyakit, tetapi pada upaya peningkatan dan pemeliharaan kesehatan serta pencegahan penyakit dan penanguulangan risiko. Masyarakat perlu dilibatkan secara aktif dalam pemeliharaan kesehatan melalui pendekatan: (1) "health gain approach" (2) "creation and production of their own health" dan (3) upaya "people's health empowerment".
\end{abstract}

Kata kunci : Paradigma pembangunan kesehatan, pembangunan manusia

\section{Abstract}

The role of health as perceived and understood by executives and legislatives in Indonesia is limited to medication of illness and curative aspect and not perceived as development of quality human resources. Since the Dutch colonial era, health policy in Indonesia is dominated by curative policy emphasizing on health facilities such as hospital, community health center, and health clinic. Those perception, policy, and effort has weakened and suppressed arguments on important roles of health in the development of nation. Newer concept of health stated that the goal of health effort is the achievement of productive health status for all meaning leading most of population to the productive health level. New definition of "health" is influencing the paradigm shift from "Health Program for Survival" to "Health Program for Human Development". The end objective of health program has changed to productive health with economic value for most of the people. WHO human rights on health includes rights of information, privacy, rights to enjoy the advancement of health technology, health education, adequate food and nutrition, optimal living standard, and social security. Therefore, health effort should not be based on illness mediaction but on the improvement and maintenance of health, disease prevention, and risk reduction. Communities should be involved actively in health preservation and promotion through (1) "health gain approach" (2) "creation and production of their own health" and (3) "people's health empowerment".

Key words : Health development paradigm, human development 
Kesenjangan pemahaman peranan, fungsi dan makna sehat antara negara maju dan negara berkembang terasa semakin melebar. Hal tersebut berakibat pada perbedaan penghargaan, penghayatan dan penempatan berbagai upaya kesehatan yang dilakukan. Di negara maju, peran kesehatan tidak lagi terbatas pada pengobatan dan penyembuhan penyakit, tetapi lebih dari itu berperan pada pembangunan ekonomi dan penyiapan sumber daya manusia (SDM) yang berkualitas guna mewujudkan masyarakat yang sehat dan sejahtera.

Di Indonesia, pemahaman pihak eksekutif dan legislatif terhadap peran kesehatan masih terbatas pada upaya pengobatan dan penyembuhan penyakit. Sementara, pemahaman mereka tentang peran kesehatan dalam membangun sumber daya manusia yang berkualitas relatif masih rendah. Selain itu, pemahaman mereka pada peran kesehatan pada pembangunan ekonomi juga masih kurang. Itulah sebabnya sampai kini upaya kesehatan di Indonesia masih bersifat kuratif, bahkan masih ada yang beranggapan bahwa penduduk sehat merupakan kontribusi pembangunan ekonomi, sementara sektor kesehatan dianggap konsumtif dan tidak produktif. Kontribusi upaya kuratif tidak besar karena tidak berdaya ungkit mengantarkan masyarakat mencapai kondisi sehat yang produktif. Membangun SDM yang berkualitas seharusnya dilakukan dalam seluruh proses kehidupan mulai dari kesehatan calon ibu, janin dalam kandungan, bayi, anak balita, usia sekolah, remaja, pemuda, kelompok usia produktif sampai usia lanjut. SDM yang berkualitas dibangun sejak usia dini sebagai bagian dari pembangunan generasi yang akan datang. Dengan demikian, dapat dipahami bahwa desentralisasi penuh bidang kesehatan tidak serta merta dapat meningkatkan derajat kesehatan masyarakat di tingkat kabupaten/kota.

Sejak zaman penjajahan Belanda, kebijakan kesehatan di Indonesia di dominasi oleh kebijakan kuratif dengan rumah sakit, puskesmas dan balai pengobatan sebagai fasilitas pelayanan kesehatan utama. Tenaga kesehatan yang tersedia umumnya adalah tenaga medis yang meliputi dokter, dokter gigi, keperawatan dan bidan. Karakteristik program kesehatan kuratif meliputi: (a) Pelayanan kesehatan yang bersifat pasif, responsif, menunggu orang sakit datang. (b) Tenaga utama adalah dokter dan perawat. (c) Tujuan utama adalah penyembuhan penyakit, meredakan kesakitan dan mencegah kematian. (d) Sasaran utama adalah individu yang sakit. (e) Kegiatan adalah padat karya, mudah dan mencari keuntungan. (f) Program bersifat hilir yang tidak efektif mencegah kesakitan. (g) Pelayanan kuratif umumnya terhimpun di kota yang banyak uang. Di samping itu, pengobatan orang sakit oleh dokter atau rumah sakit, biasanya sudah dihentikan sebelum pasien benar-benar sehat. Upaya pemulihan kesehatan orang sakit dari keadaan baru sembuh sampai ke betul-betul sehat diserahkan ke- pada keluarga. Sehingga, pasien yang berasal dari keluarga miskin umumnya akan kembali jatuh sakit.

Indikator yang sering digunakan pada upaya kesehatan kuratif antara lain meliputi cakupan pelayanan, jumlah rumah sakit, jumlah puskesmas, jumlah pustu, jumlah balai pengobatan, dan jumlah dokter per penduduk. Padahal, secara rasional jumlah dokter, rumah sakit, puskesmas yang tinggi tidak menjamin derajat kesehatan masyarakat yang tinggi. Upaya kesehatan yang bertumpu pada upaya kuratif tersebut justru memperlemah argumentasi bahwa kesehatan itu berperan penting dalam pembangunan bangsa yang menyebabkannya dianggap konsumtif dan tidak produktif. Pelayanan kesehatan kuratif sering disebut sebagai "Health Program for Survival" atau upaya kesehatan untuk mempertahankan kehidupan. Tujuan utamanya adalah meringankan penderitaan, menyembuhkan penyakit dan menghindarkan keluarga serta individu dari kematian.

Upaya kesehatan kuratif tersebut terbukti tidak menguntungkan karena melakukan intervensi setelah orang menderita sakit. Paling tidak ada empat kerugian upaya kesehatan kuratif meliputi: (a) Setelah sakit orang telah kehilangan nilai produktif dan mangkir kerja. (b) Orang harus berobat. (c) Pemulihan nilai produktif memerlukan waktu yang lama dan biaya yang besar. (d) Penderita penyakit degeneratif sulit disembuhkan atau bahkan menjadi cacat dan menjadi beban perusahaan. Dengan demikian, dapat disimpulkan bahwa kebijakan kesehatan kuratif tidak mungkin mengantarkan masyarakat mencapai kondisi sehat dan sejahtera.

\section{Makna Sehat}

Sejak lama kesehatan mendapat tempat yang mulia dan terpandang dalam peradaban manusia. Pada zaman keemasan Yunani pada sekitar 700 tahun SM, manusia menghargai kesehatan sebagai Virtue berupa sesuatu yang membanggakan sedangkan sakit adalah sesuatu yang tidak berguna. Sesungguhnya, tidak ada suatu karunia Allah sesudah iman yang lebih baik daripada sehat. Mohonlah kepada Allah keselamatan dan Afiat (HR Ibnumaajah). Schopen Hauer, menyatakan "Health is not everything but without health everything is nothing" (Kesehatan bukanlah segalanya, tetapi tanpa kesehatan segalanya bukan apa-apa). Kesehatan pada dasarnya adalah faktor dan modal utama yang diperlukan untuk membangun manusia. Dengan demikian, kesehatan merupakan prasyarat untuk membangun manusia dan kesehatan pula yang menjadi prasyarat bagi manusia untuk dapat hidup produktif. Jelaslah bahwa pada awal ataupun sepanjang kehidupan manusia, sehat/kesehatan berperan sangat penting, unik dan spesifik.

Definisi sehat menurut WHO (1948), ${ }^{1}$ "Health is state of complete physical, mental and social well being and not merely the absence of disease or imfirmity" Jika 
dicermati, definisi tersebut belum menyertakan pengertian bahwa kesehatan merupakan faktor yang penting untuk hidup produktif. Dengan demikian, dapat dimengerti jika sampai akhir tahun 1960, sehat/kesehatan hanya dipahami sebagai tujuan hidup dan belum dihubungkan dengan kepentingan pembangunan. Dengan demikian, tujuan utama pelayanan kesehatan adalah mencapai keadaan hidup sehat. Itulah sebabnya sampai kini, pengertian tersebut masih mempengaruhi upaya pelayanan kesehatan di banyak negara berkembang termasuk Indonesia. Pemahaman sehat sebagai tujuan akhir pelayanan kesehatan berdampak pada pengertian keliru yang menggambarkan keadaan sehat-sakit sebagai dihotomi hitam-putih. Tidak sakit berarti sehat, padahal itu tidak benar, karena tidak sakit tidak dengan sendirinya berarti sehat. Pada bidang kesehatan publik ada yang mempertanyakan, seberapa sehat orang yang merasa atau mengaku sehat. Dewasa ini telah dikembangkan berbagai metode untuk mengukur kesehatan positif, sehingga tingkat kesehatan seseorang dapat dideteksi secara lebih tepat.

Pada sidang di Ottawa tahun $1986,{ }^{2}$ WHO memperkenalkan konsep baru sehat produktif yang terangkum dalam The Ottawa Charter: "Health is a source of everyday life, not merely the objective of living". Konsep ini berpengaruh terhadap tujuan dari upaya kesehatan yang tidak lagi hanya sekedar mencapai kehidupan sehat individu atau masyarakat. Pada masa yang akan datang upaya kesehatan diharapkan dapat membawa setiap individu anggota masyarakat mencapai kondisi sehat produktif. Selanjutnya, WHO mengubah definisi sehat tahun 1948 menjadi definisi WHO 1988, ${ }^{3}$ yang telah memasukkan unsur sehat produktif. Sehat adalah keadaan sejahtera badan, jiwa dan sosial yang memungkinkan setiap orang hidup produktif secara sosial dan ekonomis. Definisi sehat inilah yang selanjutnya dikutip dan ditetapkan dalam UU Kesehatan R.I No. 23/1992. ${ }^{4}$ Namun demikian, jika dicermati defenisi tersebut belum mampu memperlihatkan peran unik dan spesifik bidang kesehatan dalam proses pembentukan kesehatan individu pada awal kehidupan dan selama perkembangan setiap individu.

Selain itu, definisi tersebut melemahkan argumentasi tentang peran kesehatan termasuk gizi yang penting, unik dan spesifik pada tahap awal pembentukan dan perkembangan manusia. Tanpa perkembangan kesehatan otak dan $I Q$ yang baik pada masa janin, bayi dan anak, setiap upaya pemberian nilai tambah pada manusia akan tidak optimal. Agar peran kesehatan yang penting, spesifik dan unik pada tahap awal kehidupan dan masa pertumbuhan dapat digambarkan, penulis pernah mengusulkan dalam forum diskusi "The Future Health" yang diselenggarakan oleh FKM Ul tanggal 2 Oktober 2002. Sehat perlu didefinisikan sebagai unsur potensi dasar dan alam seti- ap individu yang sangat diperlukan pada awal kehidupan dan pada masa perkembangan. Jika tidak terpenuhi, hal tersebut dapat menghambat perkembangan fisik dan mental seseorang.

Dengan batasan baru tersebut dapat diperlihatkan bahwa kesehatan di samping merupakan hak azasi juga mempunyai nilai intrinsik yang merupakan modal dengan nilai tambah dan berbagai tujuan lain dalam kehidupan. Definisi sehat tersebut perlu dibahas secara mendalam dalam The Future Health Forum atau juga organisasi kesehatan lainnya seperti Konsorsium llmu Kesehatan Indonesia (KIKI), IAKMI atau AIPTKMI. Hasil pembahasan lanjut tersebut diharapkan dapat disampaikan kepada WHO untuk dikritisi. Dalam dunia Internasional pemikiran, konsep dan pendekatan baru yang memperlihatkan peran penting kesehatan dalam pembangunan sosial dan ekonomi terus berkembang. Reformasi bidang kesehatan dan peran kesehatan dalam pembangunan berkelanjutan di negara maju sudah dimulai sejak tahun 1970. Beberapa pemikiran baru yang penting antara lain meliputi kesehatan dan pembangunan ekonomi, berbagai determinan kesehatan penduduk dan konsep sehat produktif.

\section{Kesehatan dan Pembangunan Ekonomi}

Kesehatan merupakan fungsi produksi dan modal yang tahan lama sehingga mirip dengan stok barang ekonomi lain yang dapat berkurang atau bertambah dengan pertambahan waktu atau umur. Bagi mereka yang mempunyai stok kesehatan yang selalu meningkat maka produksi mereka akan meningkat pula. Apabila stok kesehatan ditunjang dengan stok faktor lain seperti pendidikan, modal dan relasi maka nilai produksi akan lebih meningkat. Jika stok barang lain disebut $\mathrm{X}$ dan stok kesehatan adalah S maka hubungan pemanfaatan (utilitas) seseorang dapat dinyatakan dengan rumus $U=f(X, S)$. (Grossman (1972). ${ }^{5}$

Di negara maju, umumnya perusahaan dan industri telah sangat memahami konsep tersebut sehingga menaruh perhatian yang sangat besar terhadap pemeliharaan kesehatan karyawan dan manajemennya. Berbagai usaha kebugaran (wellness programe) yang dilakukan oleh perusahaan terbukti berhasil meningkatkan keuntungan perusahaan. Di negara maju, upaya untuk menurunkan kesakitan dan mengurangi hak non-produktif senantiasa dilakukan untuk mencegah kehilangan fungsi produktifitas (lost of productivity). Pemikiran tersebut dapat dipahami jika upaya kuratif terbukti tidak "cost effective" karena intervensi dilakukan terbatas pada seseorang yang telah kehilangan fungsi sehat. Sebaliknya, upaya promotif dan preventif merupakan upaya pra-investasi yang dikeluarkan dan dikembalikan dalam bentuk pencegahan kehilangan produktivitas atau pencegahan kerugian karena seseorang tidak jatuh dalam 
kondisi sakit. Seorang yang tidak sakit tentu saja dapat terus bekerja dan akan meningkatkan pendapatan sehingga mendorong pertumbuhan ekonomi masyarakat. Dengan demikian, upaya promotif preventif yang dilakukan secara tepat, jauh bersifat 'cost effective' daripada upaya kuratif.

\section{Determinan Kesehatan Penduduk}

Pelayanan kuratif lebih merupakan pelayanan penanganan penyakit individu secara episodik. Namun demikian, jika terjadi wabah maka pelayanan kuratif akan menghadapi banyak masalah karena jumlah orang yang sakit melebihi kapasitas yang dapat ditangani dalam waktu bersamaan. Pelayanan kuratif memang tidak dirancang dan disiapkan untuk menghadapi wabah seperti juga derajat kesehatan penduduk/kelompok masyarakat bukan kontribusi pelayanan medis-kuratif. Empat faktor utama yang menentukan derajat kesehatan penduduk meliputi faktor lingkungan: fisik, biologis, sosial-ekono$\mathrm{mi}(40 \%)$; faktor perilaku hidup sehat $(30 \%)$; faktor keturunan/genetika (20\%); faktor pelayanan medis (10\%). Temuan ini sangat berjasa mengubah fokus perhatian upaya kesehatan yang semula pada pelayanan medis-kuratif menjadi upaya promotif, preventif, protektif.6,7 Temuan tersebut berpengaruh terhadap gerakan baru yang lebih menekankan upaya promotif dan preventif serta mengembalikan tanggung jawab pemeliharaan kesehatan kepada individu dan masyarakat. Sesuatu yang sejak lama diserahkan sepenuhnya oleh masyarakat kepada para pelaku pelayanan medis. Upaya promotif-preventif dan peningkatan kesehatan lingkungan tidak mungkin hanya dilakukan oleh sektor kesehatan, tetapi justru diperlukan kerja sama lintas sektor. Upaya peningkatan perilaku hidup sehat masyarakat juga memerlukan kerja sama lintas sektor. Peningkatan derajat kesehatan penduduk dapat dicapai secara lebih mudah dan lebih murah melalui upaya promotif-preventif dan penanggulangan risiko daripada upaya kuratif. Upaya kesehatan lebih ditekankan pada upaya "health gain approach", "creation and production of health" and "people's health empowerment".

\section{Konsep Sehat Produktif}

Makna sehat semakin diperjelas dengan pernyataan "Health is therefore a source of everyday life, not merely the objective of living". ${ }^{2}$ Pernyataan tersebut kemudian diperkuat dalam definisi sehat baru yang memasukkan unsur sehat produktif sosial dan ekonomi. ${ }^{3}$ Definisi sehat WHO itulah yang selanjutnya diadopsi UU No. 23 tahun 1992, ${ }^{4}$ tentang kesehatan, yang masih berlaku sampai kini. Pernyataan Ottawa tersebut telah memberikan pengaruh besar terhadap berbagai program kesehatan di berbagai negara. Upaya kesehatan yang baik adalah upaya kesehatan yang dapat mengantarkan sebagian besar pen- duduknya mencapai tingkat sehat produktif bukan sekedar tingkat sehat seperti yang dialami oleh mereka yang baru saja sembuh dari sakit. Implikasi dari definisi sehat yang baru ini telah mengubah paradigma penanganan kesehatan dari "Health Program for Survival" menjadi "Health Program for Human Development". Keadaan sehat yang menjadi tujuan akhir program kesehatan, berubah menjadi keadaan sehat produktif yang mempunyai nilai ekonomis bagi sebagian besar penduduk yang harus menjadi tujuan upaya kesehatan.

\section{Kesehatan dan Pembangunan Manusia}

Pada tahun 1990, Perserikatan Bangsa-Bangsa (PBB) mencanangkan "Decade of Human Development" sebagai bagian dari "Sustainable development of mankind". Perubahan besar pemikiran peran kesehatan di negara maju tidak semuanya dapat dipahami oleh negara-negara berkembang termasuk Indonesia. Hal ini terbukti dengan lahirnya UU No. 23/1992, ${ }^{4}$ tentang kesehatan yang masih berorientasi pada upaya kuratif. UNFPA menyatakan tahun 1992 sebagai "The Year of Human Resourse Development" sebagai pertanda dimulai gerakan baru pembangunan kesehatan yang lebih menekankan pada pembangunan sumber daya manusia untuk kelangsungan pembangunan. Indikator keberhasilan yang digunakan adalah Angka Human Development Index (HDI).

Seruan PBB (1990) dan UNFPA (1992) tersebut tertampung dalam TAP MPR 1993, tetapi seruan tersebut tidak tertampung pada UU Kesehatan Rl No. 23/1992. Padahal, setelah tahun 1999, GBHN tidak pernah lagi menjadi rujukan program pemerintah. Dengan demikian, program kesehatan untuk pembangunan SDM yang berkualitas sering terlupakan. Seruan tersebut baru mendapat tanggapan yang layak pada 20 November 2005 dalam pertemuan Seruan Aksi Nasional yang dihadiri oleh Gubemur dan Ketua DPRD Propinsi seluruh Indonesia. Tingkatkan Derajat Kesehatan Masyarakat dalam rangka membangun manusia Indonesia.

\section{Kesehatan sebagai Hak Azasi}

Pelaksanaan hak azasi di negara berkembang termasuk Indonesia masih menghadapi banyak permasalahan. Hal tersebut ditandai oleh pelanggaran hak azasi berat yang masih sering ditemukan dan mudah diidentifikasi. Hak Azasi Manusia yang terkait dengan kesehatan masih sering dikategorikan pelanggaran ringan sehingga sering luput dari perhatian. Padahal, hak untuk memperoleh derajat kesehatan yang setinggi-tingginya telah diakui oleh masyarakat Internasional. Kesehatan sebagai Hak Azasi tercantum dalam: (1) Konstitusi WHO, 1946; ${ }^{1}$ (2) Universal Declaration of Human Right, 1948;2 (3) Declaration of Alma Alta, 1978;8 (4) The World Health Declaration, 1998;9 (5) General Comment on the Right to Health, 2000;10 dan (6) Special Rapporteur on the 
Right to Health, 2002. ${ }^{10}$

Menurut WHO hak azasi kesehatan merupakan hak atas informasi, hak atas privasi, hak untuk menikmati kemajuan teknologi kesehatan, hak atas pendidikan tentang kesehatan, hak atas ketersediaan makanan dan gizi, hak untuk mencapai standar hidup optimal, dan hak atas jaminan sosial. Dalam Deklarasi Universal tentang Hak Azasi Manusia artikel 25 yang juga dimuat dalam konstitusi WHO "everyone has the right to a standard of living adequate for the health and well being of himself and of his family, including food, clothing, housing and medical care"

Secara universal, pengertian hak azasi dapat dianggap sebagai hak azasi yang alami yaitu hak untuk bebas dari rasa ketakutan, kekerasan, penyiksaan, penindasan, teror, deskriminasi, kebebasan menyatakan pendapatan, ungkapan, pikiran dan lain-lain. Sampai dengan tahun 1999, Hak Azasi Manusia belum tercantum dalam UUD 1945, dia tercantum sebagai bab tersendiri setelah Amandemen ke-2, UUD 1945 pada 18 Agustus 2000. Sedangkan yang secara khusus berhubungan dengan penyediaan fasilitas pelayanan kesehatan masih berada dalam Bab XIV Perekonomian dan Kesejahteraan Sosial pasal 34 ayat 3 yang berbunyi: Negara bertanggung jawab atas penyediaan fasilitas pelayanan kesehatan dan fasilitas pelayanan umum yang layak.

Apabila pelayanan kesehatan yang tersedia hanya sebatas tingkat layak maka kesehatan penduduk yang dilayani juga hanya dapat mencapai tingkat layak. Hal tersebut menunjukan betapa minimnya pengetahuan para eksekutif dan legislatif di negeri kita tentang peran kesehatan dalam membangun dan mempersiapkan manusia Indonesia yang berkualitas. Juga untuk mengupayakan pelayanan kesehatan yang mampu mengantar sebagian besar penduduk mencapai tingkat sehat produktif. Menyelenggarakan pelayanan kesehatan yang baik adalah bagian dari upaya mewujudkan serta menegakkan hak azasi manusia. Sebaliknya, perbuatan yang merugikan kesehatan masyarakat dapat dinilai sebagai tindakan yang melanggar hak azasi dan dapat dikenakan sangsi. Implikasi kesehatan sebagai hak azasi di negara yang berpendidikan maju merupakan wujud tuntutan hak azasi yang tidak lagi terbatas pada hak memperoleh pelayanan pengobatan yang layak, tapi tuntutan untuk mendapatkan kesadaran, kemauan dan kemampuan untuk hidup sehat, sehingga tidak perlu jatuh sakit dan kehilangan nilai produktivitas.

\section{Perkembangan Program Kesehatan Negara Maju}

Sampai dengan tahun 1960-an, program pelayanan kesehatan kuratif mendominasi program kesehatan. Model pelayanan medis-kuratif dan rehabilitatif merupakan model pelayanan hilir yang bersifat pasif-responsif. Program pelayanan kesehatan yang bertujuan mencegah kematian atau "Health Program for Survival" membuat masyarakat sangat tergantung pada dokter, obat dan rumah sakit. Sebaliknya, keterlibatan masyarakat dalam memelihara kesehatan mereka sendiri terbukti rendah. Kesadaran masyarakat terhadap lingkungan, perilaku hidup sehat juga rendah. Program kuratif yang disebut program kesehatan berparadigma sakit tersebut menyebabkan biaya pengobatan terus meningkat.

Mulai tahun 1970-an melalui pemikiran baru tentang makna dan definisi sehat, tersebut di atas, negara maju memasuki era paradigma sehat. Titik berat upaya kesehatan tidak lagi pada upaya mengobati penyakit, tetapi berubah menjadi upaya peningkatan dan pemeliharaan kesehatan, pencegahan penyakit dan penanggulangan risiko. Masyarakat dilibatkan secara aktif dalam pemeliharaan kesehatan mereka sendiri melaiui pendekatan: (1) "health gain approach" (2) "creation and production of their own health" dan (3) upaya "people's health empowerment". Upaya ini merupakan upaya investasi kesehatan baik jangka pendek, menengah maupun panjang program kesehatan berparadigma sehat. Sejak tahun 1990, seluruh negara maju mengikuti seruan PBB dan UNFPA melaksanakan upaya "Human Development" (Pembangunan Manusia) dan "Human Resource Development" (Pembangunan Sumber Daya Manusia). Keduanya merupakan bagian upaya besar dunia dalam upaya "Sustainable Development of Mankind" program kesehatan berparadigma pembangunan manusia.

\section{Reformasi Kesehatan Indonesia}

Sebuah reformasi dapat muncul akibat permasalahan mendasar yang dihadapi oleh sebuah masyarakat yang jika tidak diatasi dapat mengancam kelangsungan hidup masyarakat. Di Indonesia, krisis tahun 1997 merupakan timbunan kumulatif berbagai permasalahan yang telah berlangsung sejak lama. Berbagai perubahan di tingkat internasional juga berpengaruh mendorong reformasi pada seluruh bidang kehidupan masyarakat. Salah satu persyaratan penting dari sebuah reformasi adalah berdirinya pemerintahan yang bersih dan demokratis. Reformasi pada dasarnya adalah sebuah perubahan fundamental yang menyangkut perubahan kebijaksanaan dan perubahan institusional serta sistem. Ada dua faktor penting yang berpengaruh terhadap reformasi kesehatan yang meluputi : a) Tekanan pihak luar terhadap perumusan kebijaksanaan pelayanan kesehatan. Tidak jarang reformasi kesehatan terjadi akibat perubahan yang lebih besar menyangkut perbaikan kesejahteraan masyarakat secara menyeluruh. b) Masalah di sektor kesehatan dan pelayanan kesehatan akibat keinginan untuk memperbaiki model pelayanan atau menekan biaya pelayanan yang terus meningkat. Dari sini terlihat bahwa suatu reformasi kesehatan tak dapat terlepas dari pengaruh faktor-faktor politik, ideologi, sosial, sejarah, budaya dan 
ekonomi. Reformasi timbul karena permasalahan fundamental yang dihadapi dan pemunculan pemikiran baru yang lebih maju.

Setelah pemerintahan Soeharto jatuh, Kabinet Reformasi B.J. Habibie pada tanggal 1 Maret 1999 mencanangkan reformasi bidang kesehatan yang terdiri atas 3 komponen. (1) Reorientasi program kesehatan dari paradigma sakit menjadi paradigma sehat. Upaya kesehatan lebih ditekankan pada peningkatan dan pemeliharaan penduduk sehat melalui upaya promotif, preventif, dan protektif tanpa mengabaikan yang sakit. (2) Pencanangan, gerakan pembangunan nasional yang berwawasan kesehatan, bahwa setiap program pembangunan berbagai departemen tidak boleh mengakibatkan dampak buruk terhadap kesehatan penduduk. Program pembangunan tersebut perlu dipantau agar tidak berdampak buruk seperti pencemaran tanah, sungai, danau, laut, udara, makanan. (3) Mengimplementasikan Program Indonesia Sehat 2010 dengan tujuan utama memberi kesadaran, kemauan dan kemampuan seluruh masyarakat untuk hidup sehat atau membangun kemandirian masyarakat untuk hidup sehat. Reformasi bidang kesehatan yang dicanangkan pemerintahan B.J. Habibie tersebut jika dilaksanakan secara benar akan mampu mengantar masyarakat mencapai keadaan sehat dan sejahtera serta untuk membangun SDM yang berkualitas.

\section{Perkembangan Program Kesehatan Indonesia}

Sejak zaman penjajahan Belanda sampai dengan akhir order baru (1800 - 1998) program kesehatan di Indonesia adalah upaya pelayanan pengobatan penyakit. Program kesehatan hilir tersebut bertumpu pada dokter, obat dan rumah sakit. Upaya tersebut bersifat pasif responsif, ketergantungan tinggi terhadap petugas pelayanan kesehatan atau program kesehatan berparadigma sakit. Mulai tanggal 1 Maret 1999 Kabinet Reformasi Pemerintahan B.J. Habibie mencanangkan Reformasi Kesehatan yang terdiri atas 3 komponen yaitu: (1) paradigma sehat; (2) gerakan pembangunan nasional berwawasan kesehatan, (3) implementasi Program Kesehatan Indonesia Sehat 2010. Penekanan upaya kesehatan berubah dari upaya pengobatan penyakit ke upaya promotif (peningkatan dan pemeliharaan penduduk yang tidak sakit, upaya preventif pencegahan penyakit dan upaya protektif) memberi perlindungan kepada masyarakat terhadap pencemaran, upaya penanggulangan risiko. Program kesehatan berparadigma sehat (tahun 1999-2005).

Tahun 1992 dinyatakan sebagai tahun pembangunan sumber daya manusia yang berkualitas, sesuai seruan PBB (1990) tentang "Decade of Human Development" dan Seruan UNFPA (1992) tentang "the year of human resource development. Untuk merespon hal tersebut, pada November 2005, dengan koordinasi Menko Kesra, Indonesia mencanangkan Program Aksi Nasional peningkatan derajat kesehatan masyarakat untuk membangun manusia Indonesia. Program Seruan Aksi Nasional (2005) dapat disebutkan sebagai program kesehatan yang berparadigma pembangunan manusia, yang merupakan bagian dari pelaksanaan program dunia international 'Sustainable development of mankind". Ketiga paradigma pengembangan program kesehatan di Indonesia tersebut memenuhi prasyarat implementasi pembangunan kesehatan menuju masyarakat yang sehat dan sejahtera. Pemerintah tinggal menentukan arah pembangunan kesehatan masyarakat yang menuju keadaan sehat dan sejahtera.

\section{Kendala Anggaran bidang Kesehatan}

Sejak Indonesia merdeka 17 Agustus 1945 pelaksanaan program kesehatan senantiasa secara kuantitatif yang tidak menyebutkan alokasi dana untuk kesehatan. Sejak tanggal 10 Agustus 2002, hal ini sangat berbeda dengan bidang pendidikan yang secara nyata mendapat alokasi dana dari APBN dan APBO sebanyak 20\%, walaupun dalam kenyataan baru mencapai $12 \%$. UU Kesehatan No. 23/1992 juga tidak menyebutkan alokasi dana bidang kesehatan. Sejak reformasi bidang kesehatan, pemerintah merasa perlu untuk melakukan perubahan/amandemen UU Kesehatan No. 23/tahun 1992 dan menetapkan alokasi dana kesehatan secara nyata. Namun demikian, meskipun telah berlangsung hampir 15 tahun, rencana amandemen UU Kesehatan No. 23/1992 tersebut sampai sekarang masih belum terlaksana. Dampak negatif dari keadaan ini adalah alokasi dana kesehatan di tiap daerah kabupaten/kota yang rendah. Pemerintah kabupaten/kota yang tidak menyediakan alokasi dana kesehatan tidak dikenakan sanksi melanggar konstitusi.

\section{Mencapai Masyarakat Sehat dan Sejahtera}

Uraian tersebut di atas terkait dengan berbagai pemikiran baru dalam pembangunan bidang kesehatan. Masyarakat sehat dan sejahtera yang diidam-idamkan itu tidak mungkin dicapai melalui upaya kuratif dengan paradigma sakit, tetapi melalui upaya promotif, preventif dan protektif. Tidak dicapai dengan upaya hilir yang menangani akibat, tetapi harus dilakukan melalui upaya hulu menangani sebab atau faktor risiko. Di samping itu, Indonesia perlu melakukan pembangunan SDM/manusia sebagai pembangunan "Human Capital". Pimpinan eksekutif dan legislatif di provinsi, kabupaten dan kota perlu memahami makna, peranan, fungsi sehat/kesehatan sebagai modal dasar, sebagai prasyarat pembangunan manusia. Peran kesehatan yang unik spesifik tersebut tidak tergantikan. Perlu dikembangkan kebijakan kesehatan yang proposional antara pelaksanaan paradigma sakit, paradigma sehat dan paradigma pembangunan 
manusia. Untuk melaksanakan program kesehatan hulu dan hilir secara seimbang perlu rekrutmen tenaga kesehatan hilir dan tenaga kesehatan hulu yang seimbang pula. Untuk kesehatan hulu, Badan Kepegawaian Negara telah mengeluarkan jabatan fungsional tenaga kesehatan masyarakat yang meliputi administrator kesehatan, epidemiolog, entomologi, sanitarian, penyuluhan kesehatan dan ahli gizi masyarakat yang dapat di rekrut di tingkat pusat, propinsi dan kabupaten/kota. Meskipun, pembiayaan program kesehatan terkendala peraturan dan undang-undang, pemerintah kabupaten/kota dituntut mengalokasikan dana kesehatan yang cukup. Para pimpinan eksekutif dan legislatif harus memahami peran kesehatan yang penting dalam mencapai masyarakat yang sehat dan sejahtera. Sehat adalah modal dasar pembangunan manusia dan manusia yang sehat merupakan potensi dasar mencapai masyarakat yang sejahtera.

\section{Kesimpulan}

Masyarakat yang sehat dan sejahtera harus dicapai melalui kebijakan yang menyeluruh dan tidak dilaksanakan melalui upaya kuratif atau kebijakan jangka pendek yang populis seperti pengobatan penduduk miskin gratis. Masyarakat sehat dan sejahtera harus dicapai melalui kebijakan kesehatan jangka menengah dan panjang dengan program kesehatan yang bernilai investasi ke depan. Kebijakan kesehatan yang terkait dengan pembangunan SDM/manusia yang berkualitas perlu di- arahkan pada pemembangunan manusia Indonesia yang sehat, cerdas dan kreatif melalui upaya paradigma. Pembangun SDM Indonesia yang sehat produktif dilakukan melalui paradigma Human Development sebagai "Human Capital" untuk pembangunan ekonomi. Menyediakan upaya pengobatan bagi penduduk yang terlanjur sakit (paradigma sakit).

\section{Daftar Pustaka}

1. World Health Organization. Constitution. Geneva: WHO; 1948.

2. World Health Organization. Ottawa charter for health promotion. Ottawa: WHO; 1986.

3. World Health Organization. Healthy public policy adelaide recommendation. Geneva: WHO, 1988.

4. Departemen Kesehatan RI. Undang-undang tentang kesehatan no. 23 tahun 1992

5. Grossman Michael. The demand for health: theoritical and empirical investigation. New York: Columbia University Press; 1972.

6. Lalonde, Marc. A new perspective on the health of canadians. Ottawa: Office of Canadian Minister Health and Welfare; 1974.

7. Blum, Hendrick L. Planning for health. New York: Human Sciences Press; 1974.

8. World Health Organization. Global strategy for health for all by the year 2000. Geneva: WHO; 1981.

9. World Health Organization. The yakarta declaration on leading health promotion into the $21^{\text {st }}$ century. Geneva: WHO; 1998.

10. World Health Organization. Health and human right. Geneva: Publication Series Issue No.1 WHO/PAHO; 2002. 